\title{
KOMPLEKSITAS PENGELOLAAN KAWASAN BENTENG VREDEBURG YOGYAKARTA ${ }^{25}$
}

\author{
Niken Wirasanti \\ (Pengajar Jur. Arkeologi, Fak. IImu Budaya, UGM)
}

\begin{abstract}
The development and modification of a city is an unavoidable process. However, to preserve the identity of a city is a necessity; for instance, city of Indonesian struggle for freedom, and city of culture heritage. All have been characterized with icons available throughout Yogyakarta area. The identities of Yogya as a City of Indonesian struggle for freedom and City of Culture heritage, among others, are reflected at the Benteng Vredeburg Museum and is surrounding. But at the same time various hotels and shopping mall are built nearby the site. Even though Government regulation on environmental management (Environmental Impact Analysis) have been made, however, at that location, the Cultural Heritage sites, one by one, have been destroyed and replaced by modern buildings.
\end{abstract}

Key words: warisan budaya, bangunan modern, analisis dampak lingkungan.

\section{PENGANTAR}

Bangunan-bangunan bersejarah di Yogyakarta merupakan salah satu unsur pembentuk sekaligus penanda kota. Kota Yogyakarta dikenal dengan sejumlah sebutan sebagai kota gudeg, kota pelajar, kota pendidikan, kota perjuangan kemerdekaan dan kota budaya. Sebagai kota perjuangan dan kota budaya ditandai dengan banyaknya peninggalan bangunan bersejarah yang dijumpai di berbagai lokasi dengan beragam gaya seni arsitekur, di antaranya berada di pusat kota Yogyakarta yaitu kawasan Benteng Vredeburg. Di kawasan Benteng Vredeburg inilah berdiri sederet bangunan yang dapat memberikan pengetahuan sejarah kota Yogyakarta. Bangunan-bangunan bersejarah yang mengelilingi Benteng Vredeburg mewakili rentang sejarah dari masa Kerajaan Mataram (Masa Indonesia Islam), masa pendudukan Belanda, hingga masa perjuangan kemerdekaan Bangsa Indonesia. Para pemerhati budaya sering menyebut sejumlah bangunan bersejarah yang terkonsentrasi di Kawasan Benteng

Sebagian materi pernah disampaikan dalam seminar "Kawasan Arkeologi dan Arkeologi

Kawasan Benteng Vredeburg" di Benteng Vredeburg 28 November 08. 
Vredeburg, di antaranya Gedung Agung, Gedung Senisono, Kantor Pos Pusat, Museum Sonobudoyo, Bank BNI '46, Bank Indonesia, Gedung Societeit Militer, Loji Kecil, Pabrik Paku Purosani, Pasar Beringharjo, dan Gereja Marga Mulya dengan istilah "Kawasan Nol Kilometer". Nilai penting dari kawasan ini di antaranya nilai arkeologi, sejarah, maupun nilai asosiasinya, menjadikan lokasi ini telah ditetapkan sebagai kawasan cagar budaya.

Posisi astronomis wilayah Kota Yogyakarta berada pada 110"24"19" sampai 110"28"53" Bujur Timur dan 07"15"24" sampai 07"49"26 Lintang Selatan. Wilayah kota Yogyakarta memiliki luas $32,50 \mathrm{Km}^{2}$ dengan kraton Yogyakarta sebagai pusatnya, dan berada di poros Tugu dan Panggung Krapyak. Di tengah kota tersebut mengalir tiga buah sungai dari arah utara ke selatan, yaitu Sungai Winongo di sisi sebelah barat Kraton Yogyakarta, Sungai Code di bagian tengah kota, dan sisi paling timur adalah Sungai Gadjah Wong.

$\mathrm{Di}$ antara bangunan-bangunan bersejarah tersebut tersebar permukiman penduduk. Tempat-tempat permukiman itu sering disebut kampung dan diberi nama sesuai dengan tugas dan pekerjaan dari penduduk yang menempatinya. Contoh nama kampung yang sekarang masih ada di antaranya kampung Pajeksan, tempat kedinasan para jaksa. Kampung Dagen, merupakan tempat kediaman para petugas tukang kayu. Kampung Jlagran merupakan tempat tinggal para petugas tukang batu. Kampung Gowongan, menjadi tempat tinggal para tukang ahli bangunan, Kampung Ketandan tempat tinggal penarik pajak.

Pada awal perkembangannya permukiman Kota Yogyakarta terpusat pada poros besar Utara-Selatan. Permukiman berupa kampung tempat tinggal penduduk lambat laun tumbuh di sekitar poros yang melintasi istana dari ujung utara ke ujung selatan melintasi jalan Malioboro hingga ke Tugu. Pada awal abad ke-20 pola permukiman penduduk dan struktur kota tampak cenderung semakin memusat di tengah kota (Djoko, 2005).

Dalam perjalanan waktu, kota Yogyakarta terus tumbuh dan berkembang menyebar ke segala arah, terlebih pusat kota Yogyakarta dan kawasan Benteng Vredeburg tetap menjadi sasaran pertumbuhan kota. Hal ini ditandai dengan munculnya bangunan-bangunan baru dan hancurnya bangunan-bangunan bersejarah di tempat itu. Perubahan yang menjadi bagian dari kemajuan harus dibayar mahal dengan berubah dan hilangnya satu persatu bukti dan identitas kota yang ada di kawasan Benteng Vredeburg. Dimulai dengan hancurnya gedung kesenian/Art Gallery Senisono (Societeit de Vereeneging/tyokan kantai/Balai Mataram), Lembaga Kantor Berita Nasional Antara, kantor PWl yang saat ini telah menyatu dengan Gedung Agung. Ke arah timur dari Benteng Vredeburg pernah berdiri perusahan besi Purosani (NV Contructie Atelierder Vorstenlanderl Yogyakarta Kikai Seisaku Sio) yang saat ini menjadi Hotel Melia Purosani, dan berubahnya permukiman Loji Kecil menjadi deretan pertokoan, dan renovasi besar-besaran dari Pasar Beringharjo menjadi pusat perbelanjaan. Di tambah lagi tepatnya sebulan yang lalu (Juli 2009) di 
Kawasan Benteng Vredeburg baru saja diresmikan bangunan modern pusat perbelanjaan berlantai 4 dan satu basement yaitu mall Toko Progo. Hadirnya bangunan hotel dan pusat-pusat perbelanjaan yang skalanya gigantik seakan-akan menjadi kebutuhan masyarakat kota yang ingin secara mudah memperoleh barang-barang kebutuhan sehari-hari dalam satu bangunan. Fakta tersebut menjadikan Kawasan Benteng Vredeburg yang telah ditetapkan menjadi kawasan cagar budaya menghadapi permasalahan yang kompleks terkait dengan kelestarian kawasan seiring dengan pertumbuhan kota Yogyakarta. Fungsi penggunaan lahan di kawasan Benteng Vredeburg dengan harapan menjadi ruang publik kota yang penuh makna kultural, tampaknya harus bersaing dengan fungsi kawasan sebagai pusat perbelanjaan. Masyarakatpun seakan tidak puduli dengan perubahan yang terjadi di kotanya.

Tulisan singkat ini bermaksud mengemukakan permasalahan yang ingin dijawab terkait dengan seperti apa perubahan yang terjadi menyangkut profil kawasan benteng Vredeburg dan instrumen apa yang diperlukan untuk pengelolaan kawasan cagar budaya. Secara singkat akan diuraikan profil kota Yogyakarta yang terus berubah dan relevansi studi AMDAL dalam pengelolaan kawasan cagar budaya.

\section{IDENTITAS YOGYAKARTA DAN PERUBAHANNYA}

Kota Yogyakarta memiliki kekuatan dengan karakter dengan identitas yang dimiliki sebagai kota perjuangan dan kota budaya. Kota merupakan artefak terbesar dari karya manusia dan komunitasnya. Untuk itu berbagai upaya dilakukan untuk menjaga karakter dan sifat beda kota Yogyakarta dengan kota-kota lain. Identitas kota harus dipertahankan dan dilestarikan untuk menjadi kebanggaan seluruh warga masyarakat khususnya Yogyakarta.

Dalam sejarahnya kota Yogyakarta dikenal sebagai kota Istana atau kota kerajaan yang dibangun tahun 1756 oleh Sultan Hamengku Buwono I (Pangeran Mangkubumi). Awal pembangunan kota Yogyakarta, dimulai dari perjanjian Giyanti (1755) yang memisahkan Mataram menjadi dua, Yogyakarta dan Surakarta. Pada awalnya kraton berada di Ambarketawang, yang berada di sebelah barat kota Yogyakarta. Beberapa waktu kemudian kraton dipindahkan dari Ambarketawang menuju Hutan Beringan oleh Pangeran Mangkubumi. Kota Yogyakarta merupakan kota tradisional yang dibangun melalui sebuah perencanaan dengan konsep beserta filosofi pembangunan kota berdasarkan pandangan kebudayaan yang berlaku dalam masyarakat. Artinya raja mendirikan pusat permukiman dengan konsep babad alas, dilanjutkan membangun istana sebagai pusat pemerintahan kerajaan dan sekaligus pusat permukiman warga kota kerajaan di sekitarnya. Kota Yogyakarta diyakini dirancang dengan tata ruang yang menghubungkan Parangkusumo - Panggung Krapyak - Kraton - Tugu dan Gunungapi Merapi yang membujur dari selatan ke Utara. Otto 
Sumarwoto kurang sependapat dengan sejumlah pendapat yang menyebut lokasi tersebut poros selatan - utara sebagai Poros Imaginer, tetapi lebih tepat disebut "Poros Simbolis - Filosofis Selatan-Utara dan Kraton Yogyakarta (Djoko, 2005).

Arah poros inilah yang menjadi awal arah pertumbuhan kota, yang kemudian disusul dengan arah Timur-Barat. Selanjutnya dijelaskan dinamika perkembangan kota Yogyakarta banyak dipengaruhi perubahanperubahan politik dari masa kolonial hingga masa kemerdekaan. Berbagai peristiwa bersejarah terjadi di kawasan ini, mulai dari pendudukan Belanda ditandai dengan munculnya bangunan-bangunan kolonial, dilanjutkan alih kekuasaan oleh Jepang, hingga direbut dan dikuasai oleh pemerintah RI. Selain Kraton, alun-alun utara, masjid dan pasar Beringharjo yang lebih dulu ada, terdapat sejumlah bangunan telah menjadi saksi dari peristiwa bersejarah tersebut, diantaranya Benteng Vredeburg dan Societeit Militer, Istana Negara (Gedung Agung), Societeit de Vereeniging Djokjakarta (Gedung Senisono), Bank BNI '46 (Nedrlandsch-Indische Liff en Levenswerzekering Maatschappij), Museum Sonobudoyo, Kantor Pos Yogyakarta (PTT - Post Telegraaf en Telefoon Kantoor), Bank Indonesia (Javasche Bank), Pabrik Besi Purosani (NV Contructie Atelierder Vorstenlander/ Yogyakarta Kikai Seisaku Sio. Pada waktu itu permukiman kota khususnya kawasan benteng Vredeburg semakin plural sebagai akibat semakin banyak orang-orang asing yang tinggal di Yogyakarta, selain orang Cina, orang Belanda banyak yang tinggal di kota ini. Mereka menempati kampung Pecinan (Ketandan), Kampung Beskalan, Kampung Sayidan, Kampung Kranggan, dan Loji Kecil.

Dari tahun ke tahun seperti kota-kota besar lainnya, Yogyakarta juga menghadapi persoalan yang sama yaitu pemekaran fisik kota. Sejumlah konsekwensi muncul terkait pemekaran kota, mulai dari peremajaan kawasan, pelebaran jalan dan pejalan kaki, sampai dengan kebutuhan lahan parkir. Seiring dengan pertumbuhan kota Yogyakarta yang pesat, kawasan Benteng Vredeburg juga berubah. Membandingkan dengan kotakota lainnya, masyarakat Yogyakarta mestinya harus bangga memiliki Benteng Vredeburg yang masih megah berdiri di tengah kota, sementara Benteng Vastenburg di Solo yang dilihat dari letak, fungsi, bentuk dan denah bangunan serta kesamaan latar belakang dengan Benteng Vredeburg, kini yang tersisa hanya tembok keliling sedangkan bangunan di dalamnya telah runtuh. Namun tidak demikian halnya dengan sejumlah bangunan bersejarah lainnya di kawasan Benteng Vredeburg yang mulai hilang atau berubah di antaranya Gedung Senisono, Pabrik Besi Purosani, perkampungan Loji Kecil, dan pemekaran sekaligus renovasi pasar Beringharjo.

Gedung Senisono pada awal tahun 1822 bernama Societeit de Vereeniging ketika menjadi milik perkumpulan orang Eropa. Pada masa Jepang berubah nama menjadi Tyokan Kantai, sedangkan Sultan Hamengkubuwono IX memberi nama Balai Mataram. Balai Mataram pada masa kemerdekaan menjadi tempat Konggres Pemuda Indonesia yang 
pertama, dan dalam sejarahnya pernah dihancurkan sehingga yang tersisa adalah gedung tempat pertunjukan. Setelah kemerdekaan tahun 1950 berfungsi menjadi gedung bioskop dan tahun 1970 di jadikan art gallery. Satu kompleks dengan Senisono adalah kantor PWI Yogyakarta, dan lembaga Kantor Berita Nasional (Arwan dan Heddy Shri Ahimsa-Putra, 2004). Saat ini bangunan tersebut telah direnovasi menyatu dengan kompleks Gedung Agung. Bangunan bersejarah Senisono yang berada di sudut Barat laut dari benteng Vredeburg kini tinggal kenangan.

Permukiman di kawasan benteng Vredeburg yang saat ini juga tinggal kenangan adalah permukiman masyarakat Eropa pertama di Yogyakarta yang terletak di sebelah timur benteng Vredeburg dan dikenal dengan sebutan Loji Kecil. Istilah ini digunakan untuk membedakan dengan permukiman di dalam benteng yang disebut dengan Loji Gedhe atau Loji Besar. Sebagai permukiman lama kondisi Loji Kecil sudah berubah, yang semula permukiman orang Eropa sekarang menjadi bagian dari pusat perdagangan. Saat ini masyarakat tidak mengingat lagi nama Loji Kecil (Sektiadi, 2002).

Pasar Beringharjo yang berada di sebelah utara benteng Vredeburg pada awalnya bernama Pasar Gedhe, yang dibangun di Alas Bring, yang terletak di desa Pacetokan. Pasar Beringharjo merupakan pasar terbesar di kota Yogyakarta yang dibangun bersamaan dengan pendirian kota Yogyakarta (Gegevens Over Djokjakarta, 1926). Bangunan beringharjo saat ini terdiri dari 3 lantai dengan luas lahan lebih dari $25.000 \mathrm{~m}^{2}$. Bagian depan atau pintu masuk pasar masih tetap dipertahankan seperti keadaan awal berdirinya.

Atas nama pembangunan kadang tak memberi toleransi pada bangunan-bangunan bersejarah yang menurut sebagian masyarakat dianggap penghambat pembangunan kota. Satu lagi bangunan yang hancur adalah pabrik besi Purosani yang berada di sisi Timur Laut dari kawasan Benteng Vredeburg. Pada tahun 1900 pabrik ini dikenal dengan nama NV. Constructie Atelieder Vorstenlander. Produksi yang dihasilkan adalah panci, wajan, dandang, cangkul, dan rem kereta api. Masa Jepang tahun 1942 Purosani berganti nama Yogyakarta Kikai Seisaku Sio dengan produksinya berupa mesin kapal dengan kapasitas 115 pk, mortir, dan pedang (Arwan dan Heddy Shri Ahimsa-Putra, 2004). Kira-kira sepuluhan tahun yang lalu pabrik besi Purosani akhirnya diruntuhkan diganti dengan hotel berbintang lima Melia Purosani. Saat ini berhimpit dengan hotel Melia dan permukiman Cina (Ketandan), telah berdiri mall toko Progo berlantai lima dengan basement. Sedikit ke luar dari kawasan benteng Vredeburg, yaitu kawasan Malioboro yang melegenda sejak berdirinya kota Yogyakarta, juga telah berubah bentuk menjadi kawasan pusat perbelanjaan, ditandai dengan hadirnya mall dan pusat perbelanjaan.

Pesatnya proses modernisasi menjadi salah satu pemicu perubahan. Hotel dan pusat perbelanjaan dibangun berhimpitan dengan bangunan-bangunan bersejarah. Benarkah kehadiran bangunan hotel dan pusat-pusat perbelanjaan memberikan jaminan tetap terciptanya lingkungan 
yang selaras dan serasi dengan mempertimbangkan kaidah pelestarian lingkungan budaya. Nampak bahwa orientasi pertumbuhan kota berorientasi pada pertumbuhan ekonomi. Sementara mestinya perlu dipahami bahwa kekuatan ekonomi pasar saat ini bicara dalam hitungan tahun, tatapi kekuatan budaya yang dimiliki pada hasil karya seni bangun tidak akan terukur oleh satuan waktu (Bagoes, 1995). Menjaga kelestarian bangunan cagar budaya dan kawasannya sebenarnya sudah dimulai sejak masa penjajahan Belanda. Sejak tahun 1931 Indonesia (Hindia Belanda) sudah memiliki Monumenten Ordonantie Nr 238 mengenai perlindungan terhadap bangunan bersejarah. Pada tahun 1992 Undang-Undang tersebut direvisi menjadi Undang-Undang Benda Cagar Budaya (BCB) Nomer 5 Tahun 1992. Namun demikian tampaknya Undang-undang tersebut belum memberikan jaminan bangunan bersejarah tidak dihancurkan. Salah satu contohnya dapat kita lihat bangunan-bangunan di Kawasan Cagar Budaya Benteng Vredeburg yang satu persatu telah berubah menjadi bangunan modern.

Undang-Undang lainnya yang dapat dijadikan acuan untuk menjaga kelestarian kawasan cagar budaya yaitu UU Pengeloaan Lingkungan Hidup nomer 23 Tahun 1997 yang menyebutkan persyaratan dilakukannya studi kelayakan untuk proyek-proyek pembangunan yang berdampak penting pada lingkungan (termasuk dampaknya pada BCB). Selanjutnya turut memperkuat peraturan tersebut adalah Peraturan Menteri Negara Lingkungan Hidup No 08 tahun 2006 tentang Pedoman Penyusunan Analisis Mengenai dampak Lingkungan Hidup (AMDAL). Tampaknya UU Pengelolaan Lingkungan Hidup, khususnya studi AMDAL belum pula populer dipahami oleh masyarakat terkait dengan kegunaannya untuk mencegah dan meminimalisir terjadinya dampak negatif oleh suatu rencana kegiatan. Hal yang perlu segera diapresiasi bahwa AMDAL merupakan instrumen bagi pengelolaan lingkungan hidup, baik bagi pemrakarsa sebagai pengelola, instansi terkait sebagai pengawas, maupun masyarakat sebagai penerima dampak jika terjadi penurunan kwalitas lingkungan hidup.

Pembangunan mall toko Progo yang berada di kawasan Benteng Vredeburg telah dilengkapi dengan studi AMDAL, demikian pula tentunya AMDAL Hotel Melia Purosani atau AMDAL untuk bangunan-bangunan lainnya di kawasan tersebut. Hasil studi AMDAL menyebutkan pembangunan mall Toko Progo tidak berdampak negatif pada aspek sosial budaya, khususnya kawasan Benteng Vredeburg. Namun demikian masih tersirat kekhawatiran mengingat Kawasan Benteng Vredeburg saat ini telah menjadi kawasan yang sangat padat, karena sebagian kawasan telah menjadi pusat perbelanjaan. Sebelum mall toko Progo dibangun, pelan tapi pasti sebagian kawasan Benteng Vredeburg telah berubah menjadi pusat perdagangan dan diikuti dengan perbaikan sarana prasarana berupa jalan, lahan parkir, dan pejalan kaki. Pasar Beringharjo direnovasi menjadi tiga lantai, Kawasan Loji kecil berubah menjadi deretan toko-toko grosir, yang masih ada adalah kawasan Ketandan yang bertahan sebagai permukiman Pecinan. Dalam teori kebudayaan dikenal istilah sosio genesis kebudayaan 
yang artinya kebudayaan akan terikat oleh boundary yang mengitarinya. Untuk itu muncul dalam benak para pemerhati budaya, mampu bertahankah jejak-jejak warisan budaya di kawasan Benteng Vredeburg bersanding dengan sentra-sentra perdagangan yang terus berkembang. Waktu yang nantinya akan membuktikan seberapa lama keberadaan permukiman bersejarah dapat bertahan.

Kekhawatiran tersebut dapat dipahami melihat perkembangan sebagian kawasan Benteng Vredeburg yang telah berubah menjadi kawasan modern yang semakin lama semakin padat. Selain itu kekhawatiran muncul mengingat masih sering terjadi bahwa hasil studi AMDAL tidak menjadi panduan dalam kegiatan proyek pembangunan, juga upaya pengelolaan lingkungan dan upaya pemantauan lingkungan. Dengan kata lain beberapa pihak masih menganggap penyusunan studi AMDAL sebatas kelengkapan administrasi, bukan menjadi alat untuk menjaga kelestarian daya dukung lingkungan. Bahkan masih sering muncul pertanyaan apa manfaat dan hakekat melestarikan bangunan-bangunan bersejarah bagi masyarakat kota. Apapun jawabannya, yang jelas makna hakiki dari pentingnya bangunan-bangunan bersejarah di kawasan Benteng Vredeburg adalah kontribusi memorialnya dalam membentuk karakter lingkungan binaan di sekitarnya. Artinya di kawasan ini eksistensi bangunan-bangunan bersejarah berperan membangkitkan pengetahuan individu atau komunitas akan suatu tempat, sekaligus menjadi pegangan visual masyarakat kota dalam berorientasi. Dari pusat kota inilah Yogyakarta hadir, tumbuh dan berkembang.

Suatu kota pasti mengalami perkembangan baik secara fisik maupun non fisik, dan yang perlu dilakukan adalah cara menjaga penanda sebuah kota dari berbagai ekspresi baru di sekitarnya. Kawasan Benteng Vredeburg yang keberadaannya tidak dapat dipisahkan dengan kawasan Malioboro terus mengalami perubahan. Kawasan Malioboro telah menjadi tujuan wisata belanja para wisatawan domestik maupun luar negeri. Peremajaan bangunan-bangunan modern dapat disaksikan di kawasan Malioboro yang lokasinya berada di sebelah utara kawasan Benteng Vredeburg. Salah satu bangunan yang masih mempertahankan ciri bangunan bersejarah adalah Apotik Kimia Farma.

\section{INSTRUMEN PENGELOLAAN KAWASAN BENTENG VREDEBURG}

Perubahan suatu kota merupakan hal yang wajar, namun demikian kalau kemudian penanda kota hilang dan menjadi seragam dengan kotakota lain maka ciri khas dan identitas kota tidak lagi menjadi daya tarik dan kota itu akan dilupakan. Asumsinya masyarakat akan bangga dengan kotanya apabila di kota tersebut terdapat sejumlah obyek atau penanda yang memberi makna dan kenangan bagi siapapun yang mengunjungi kota tersebut. Yogyakarta yang dikenal dengan kota perjuangan dan kota budaya tentunya patut menjaga predikat tersebut dengan cara menjaga 
bangunan yang menjadi saksi sejarah perjuangan dan sekaligus perkembangan lingkungan binaan. Upaya menjaga citra Yogyakarta sebagai kota perjuangan telah dilakukan, yaitu dengan pemugaran dan SK penetapan pada sejumlah bangunan bersejarah, sebut saja Bank BNI ' 46 , Bank Indonesia, dan Benteng Vredeburg. Selain itu telah pula berdiri sejumlah museum yang memajang foto-foto perjuangan dan beragam peralatan perang. Namun demikian upaya untuk menjaga lestarinya sebuah kawasan cagar budaya masih belum maksimal, dan belum didukung oleh seluruh warga masyarakat Yogyakarta.

Untuk menjaga identitas suatu kota tentunya diperlukan instrumen pengelolaan lingkungan. Sebelum masalah lingkungan hidup gencar dibicarakan seperti akhir-akhir ini, proyek pembangunan yang akan dilakukan yang menimbulkan dampak penting pada daya dukung lingkungan disyaratkan/dilengkapi dengan studi kelayakan teknis dan kelayakan ekonomis (Peraturan Pemerintah nomer 29 Tahun 1982). Namun sejak dikeluarkannya UURI Nomer 4 Tahun 1982 yang kemudian diganti dengan UU nomer 23 tahun 1997 tentang Pengelolaan Lingkungan Hidup dan diterbitkannya peraturan pendukungnya, maka semua proyek pembangunan yang diperkirakan menimbulkan dampak penting pada aspek lingkungan hidup harus dilengkapi dengan studi kelayakan lingkungan yang ditunjukkan oleh hasil studi yang disebut dengan AMDAL (Analisis Mengenai Dampak Lingkungan) (Karden, 2003). Studi AMDAL adalah studi ilmiah yang mengkaji semua aspek lingkungan yang bersifat multisidiplin dan multikompleks. Kerangka studinya dipengaruhi oleh paradigma holistikekologis, sehingga kajian harus bersifat lengkap dan komprehensif. Selain itu perlu dihindari kecenderungan untuk memusatkan perhatian pada ilmuilmu keras, tetapi harus ada keterbukaan untuk melihat realitas dan masalah lingkungan hidup dari cara pandang ilmu-ilmu sosial-budaya (Sonny, 2002). Oleh karena dokumen ini merupakan studi kelayakan lingkungan yang berisi sejumlah prakiraan dampak penting yang akan dievaluasi dan dilanjutkan dengan desain rencana pengelolaan dan pemantauan, maka dokumen AMDAL disusun sebelum proyek pembangunan dilakukan. Dokumen AMDAL terdiri dari empat yaitu dokumen Kerangka Acuan, dokumen Analisis Dampak Lingkungan (ANDAL), dokumen Rencana Pengelolaan Lingkungan (RKL) dan dokumen Rencana Pemantauan Lingkungan (RPL).

Selanjutnya dijelaskan bahwa penerapan studi kelayakan lingkungan merupakan wujud dan penopang konsep pembangunan berwawasan lingkungan yang telah dicanangkan di Indonesia. Untuk itu kegiatan pembangunan dan hasilnya diharapkan tidak hanya bersifat sementara, tetapi berkelanjutan dari satu generasi ke generasi berikutnya. Studi kelayakan lingkungan tersebut bertujuan untuk meminimalisir dampak negatip yang diperkirakan akan muncul oleh suatu rencana usaha/kegiatan dan selanjutnya disusun alternatif pencegahan dan penanggulangan dampak negatif. Dengan kata lain aktivitas pengelolaan (RKL) dan pemantauan (RPL) terhadap bangunan/kawasan cagar budaya dapat disusun apabila telah diketahui hasil prakiraan dampak dan hasil evaluasi 
dampak negatif pada lingkungan akibat dari proyek-proyek pembangunan yang akan dibangun. Artinya apabila perhitungan prakiraan dan hasil evaluasi dampak tidak menujukkan dampak penting pada kawasan cagar budaya (dalam hal ini kawasan Benteng Vredeburg), maka tidak ada rekomendasi yang tertuang dalam Rencana Pengelolaan Lingkungan (RKL) dan Rencana Pemantauan Lingkungan (RPL).

Hasil studi itu diperlukan bagi proses pengambilan keputusan tentang penyelenggaraan usaha dan atau kegiatan. Untuk itu diharapkan penyusunan studi AMDAL dilakukan secara benar dan konsisten agar dapat memberikan jaminan ke depan terkait dengan kelestarian daya dukung lingkungan dan daya tampung suatu kawasan (termasuk kelestarian kawasan cagar budaya). Penyusunan dokumen AMDAL merupakan tanggung jawab pemrakarsa yang dalam pelaksanaan dapat dibantu oleh konsultan. Aspek yang harus dikaji adalah empat aspek lingkungan yang saling kait mengkait, yaitu aspek fisik, biotis, sosial-budaya (termasuk benda cagar budaya), dan aspek kesehatan masyarakat. Artinya setiap tahapan dalam kegiatan proyek pembangunan harus dilakukan perhitungan secara cermat dampaknya pada aspek fisik, biotis dan sosial-budaya juga kesehatan masyarakat.

Sebagai contoh, proyek pembangunan yang berhimpit atau berdekatan dengan bangunan atau kawasan cagar budaya perlu memperhitungkan dampak berbagai aktivitas pembangunan terhadap bangunan cagar budaya yang ada di sekitarnya. Aktivitas proyek pembangunan di kelompokkan menjadi tiga tahap yaitu tahap prakonstruksi, konstruksi, dan operasional, terkadang ada tahap pascaoperasional. Dalam tahap prakonstruksi biasanya dilakukan persiapan atau rekrutmen tenaga kerja, kegiatan pembersihan lahan, dan pada tahap konstruksi terdapat sejumlah kegiatan diantaranya mobilisasi alat berat mengangkut material bahan bangunan, dan aktivitas pemasangan tiang pancang. Tahap operasional diantaranya berupa rekrutmen karyawan-karyawan mulai dari tenaga parkir hingga pimpinan, tahap pascaoperasional apabila tidak ada aktivitas lagi alias kontrak habis atau tutup sehingga terjadi pelepasan tenaga kerja.

Dari tiga tahapan tersebut contoh kegiatan yang sering menimbulkan dampak negatif pada bangunan adalah tahap konstruksi dan operasional. Saat alat-alat berat beroperasi terkait pemasangan tiang pancang bangunan, perlu diprediksi apakah bangunan cagar budaya tetap utuh atau menjadi retak-retak bahkan mungkin runtuh akibat getaran yang berasal dari kerja alat-alat berat tersebut. Selain itu, saat proyek pembangunan (tahap operasional) sudah selesai apakah bangunan-bangunan cagar budaya yang ada di sekitarnya tetap lestari atau sebaliknya pelan tapi pasti bangunan cagar budaya akan semakin tidak terawat, kemudian dibongkar menjadi bangunan modern.

Masyarakat menganggap perubahan itu layak dilakukan mengingat dari segi keindahan sangat kontras bangunan modern bersanding dengan bangunan bersejarah yang cenderung kusam dan tidak terpelihara. Oleh 
karenanya dianggap sudah saatnya kalau bangunan-bangunan bersejarah tersebut berganti menjadi bangunan baru. Hal inilah yang dikawatirkan oleh sejumlah pemerhati budaya, terkait dengan banyaknya bangunan modern di Kawasan Benteng Vredeburg. Permukiman Loji Kecil telah hilang, apakah permukiman Pecinan di Ketandan, dan permukiman bersejarah lainnya juga akan beralih bentuk sebagai pertokoan atau fungsi lainnya. Kondisi tersebut menjadi fokus kajian aspek sosial budaya dalam studi AMDAL. Untuk itu apabila hasil Analisis Dampak Lingkungan (ANDAL) menunjukkan bahwa kegiatan pembangunan yang akan dilakukan menimbulkan dampak penting pada kawasan cagar budaya, maka di dalam dokumen AMDAL akan disusun alternatif pengelolaan dan memantau kondisi bangunan cagar budaya pada setiap periode tertentu sebagai dasar tindakan pengelolaan lingkungan secara berkelanjutan. Kajian tersebut tertuang dalam dokumen Rencana Pengelolaan (RKL) dan dokumen Rencana Pemantauan Lingkungan (RPL). Sudah selayaknya studi AMDAL sebagai instrumen pengendali dampak lingkungan hidup mestinya dapat dipahami posisinya yang penting, baik bagi pemrakarsa sebagai pengelola, instansi terkait sebagai pengawas atau pemantau, maupun bagi masyarakat sebagai penerima dampak jika terjadi perubahan lingkungan.

Peran studi AMDAL yang strategis dalam mengendalikan dampak lingkungan, menjadikan suatu keharusan bagi berbagai pihak untuk meyamakan persepsi dan kesamaan langkah dalam mengantisipasi berbagai kemungkinan terjadinya kerusakan atau hilangnya bangunan cagar budaya di suatu kawasannya. Keputusan di bidang lingkungan hidup harus dilihat sebagai pilihan etis. Dengan demikian, pertanggung-jawaban moral adalah bagian yang tidak dapat dipisahkan dan diabaikan dari setiap keputusan di bidang lingkungan hidup (Sonny, 2002).

Langkah pertama yang diperlukan adalah tersedianya data yang terkait dengan karakteristik benda cagar budaya sehingga dapat dipergunakan dalam kajian studi AMDAL. Yang terjadi saat ini data yang tersedia tentang benda atau kawasan cagar budaya lebih bersifat inventarisasi, sehingga menyulitkan para penyusun AMDAL dan komisi penilai AMDAL untuk mengetahui dampak positip-negatip yang ditimbulkan dari kegiatan proyek pembangunan dan sekaligus kesulitan dalam mengelola bangunan cagar budaya dan kawasannya. Untuk itulah dari sejumlah dokumen AMDAL, hasil pengamatan prakiraan dampak proyek pembangunan pada bangunan cagar budaya dan kawasannya belum memuaskan. Hal ini menyiratkan kesan kajian aspek sosial-budaya AMDAL (bangunan cagar budaya dan kawasannya) belum dianggap penting di kalangan masyarakat. Hingga saat ini Kementrian Lingkungan Hidup terus melakukan revisi terkait dengan panduan penyusunan AMDAL sehingga diharapkan kelestarian daya dukung dan daya tampung lingkungan (aspek fisik, biotis, sosial-budaya/cagar budaya, dan kesehatan masyarakat) tetap terjaga.

Langkah kedua yang perlu dilakukan adalah keikut sertaan para pemerhati atau instansi budaya, juga masyarakat dalam melakukan 
penilaian dokumen AMDAL, baik di tingkat kabupaten, propinsi, ataupun nasional. Dokumen AMDAL merupakan dokumen yang terbuka untuk umum, artinya setiap orang dapat membaca, mengoreksi dan sekaligus memberi masukan. Dalam penilaian dokumen AMDAL itulah instansi yang berwenang menangani benda/kawasan cagar budaya dan masyarakat khususnya pemerhati budaya dapat hadir dan ikut berpartisipasi memberikan masukan. Keterlibatan masyarakat dalam penyusunan dokumen AMDAL telah dituangkan dalam Keputusan Kepala Badan Pengendalian Dampal Lingkungan Nomer 08 tahun 2000 tentang Keterlibatan Masyarakat dan keterbukaan Informasi dalam Proses Analisis mengenai Dampak Lingkungan Hidup.

Terkait dengan keberadaan sejumlah mall, hotel berbintang dan bangunan -bangunan modern lainya yang saat ini telah eksis, sudah saatnya berbagai pihak peduli seandainya terjadi perubahan yang berakibat dengan hilangnya sejumlah identitas bersejarah di kawasan Benteng Vredeburg. Apabila hal itu terjadi, maka dimungkinkan dilakukan revisi dalam dokumen Rencana Pengelolaan (RKL) dan Pemantauan (RPL). Selain itu pemrakarsa juga dapat melakukan Audit Lingkungan. Dengan kata lain berdirinya hotel berbintang dan mall di kawasan Benteng Vredeburg akan menjadi saksi apakah bangunan skala gigantik tersebut mampu memberikan jaminan bahwa kawasan benteng Vredeburg akan tetap lestari, dan tetap menjadi penanda kota Yogya. Sudah saatnya dan semestinya dukumen AMDAL dijadikan acuan dalam pengelolaan lingkungan (kawasan cagar budaya). Penyusun AMDAL bidang aspek sosial budaya harus mampu mempredikasi dan sekaligus mengevaluasi dampak lingkungan dan selanjutnya menyusun alternatif rencana pengelolaan dan pemantauan kondisi bangunan cagar budaya yang diprediksi terkena dampak dari suatu kegiatan yang akan dibangun.

\section{PENUTUP}

Menjaga bangunan cagar budaya dan kawasannya merupakan persoalan yang kompleks, tarik-menarik kepentingan berbagai pihak ditambah sikap tidak peduli masyarakat terhadap makna bangunan cagar budaya menjadikan masalah tersebut selalu menarik untuk ditulis. Peremajaan kota ke arah yang lebih baik merupakan tujuan yang logis dari pembangunan. Namun tidak etis apabila pembangunan suatu kota harus menghilangkan identitas kota, dan tidak ada pembeda dengan kota-kota lainnya. Kota Yogyakarta memiliki banyak identitas yang menjadi ciri khas dan akan menjadi daya tarik apabila warga masyarakat mampu menjaga makna kulturalnya. Berbagai cara tentunya harus diupayakan untuk menjaga identitas tersebut. Menjaga kelestarian bangunan bersejarah telah dilakukan, akan tetapi menjaga kelestarian kawasan cagar budaya belum maksimal dikerjakan. 
Salah satu intrumen pengendali dampak lingkungan (termasuk dampak pada kawasan cagar budaya) yaitu studi AMDAL. Namun demikian prosedur dan substansi kajian studi kelayakan Lingkungan (AMDAL) khususnya yang berhubungan dengan kawasan cagar budaya belum dilakukan secara serius oleh berbagai pihak. Pemerintah tampaknya masih menganggap studi AMDAL adalah satu-satunya instrumen pengelolaan lingkungan. Bagi pemrakarsa masih ada kesan bahwa AMDAL merupakan dokumen kelengkapan administrasi atau salah satu persyaratan formal untuk mendapatkan ljin Mendirikan Bangunan (IMB). Adapun bagi penyusun AMDAL kajian lebih sering terfokus pada aspek fisik, sedangkan aspek sosial budaya cenderung kurang mendapat perhatian. Indikasinya, hilang atau rusaknya benda cagar budaya dan kawasannya dianggap merupakan konsekwensi logis dari suatu perubahan kota, sehingga tidak perlu dipermasalahkan. Lebih tragis, perubahan lingkungan budaya yang ditandai dengan hancurnya bangunan cagar budaya cenderung ditoleransi oleh masyarakat karena dianggap tidak menimbulkan kerugian yang berarti pada manusia.

Hal yang lebih memprihatinkan, dokumen AMDAL yang mestinya menjadi acuan dalam pengelolaan lingkungan (kawasan cagar budaya) tampaknya juga belum mendapat banyak perhatian. Artinya saat proyek pembangunan selesai dan mulai beroperasi, dokumen AMDAL tidak lagi berfungsi untuk kegiatan pengendali dampak lingkungan, tetapi yang sering terjadi dokumen AMDAL menjadi arsip di almari perpustakaan. Perangkat atau instrumen untuk menjaga kelestarian kawasan cagar budaya telah tersedia, selanjutnya studi AMDAL harusnya menjadi suatu kewajiban yang mengikat semua pihak dalam upaya menjaga kelestarian kawasan cagar budaya, termasuk kawasan Benteng Vredeburg. 


\section{KEPUSTAKAAN}

Aca Sugandi, Rustam hakim, 2007, Prinsip Dasar Kebijakan Pembangunan Berkelanjutan Benwawasan Lingkungan, Jakarta: Bumi Akasra.

Arief Ramelan Karseno (ed),2004, dari Jogja untuk Indonesia, Yogyakara: Inspect.

Arwan Tuti Arta, Heddy Ahimsa-Putra, 2003, Jejak Masa Lalu Sejuta Warisan Budaya, Yogyakarta; Kunci IImu.

Bagoes P Wiryomartono, 1995, Seni bangunan dan Seni Binakota di Indonesia, Jakarta: Gramedia.

Djoko Suryo 2005, terj, " Pendudukan dan Perkembangan Kota Yogyakarta 1900-1990", kota Lama Kota Baru, Sejarah Kota-kota di Indonesia, Yogyakarta, Penerbit ombak.

Gegevens Over Djokjakarta, 1926, dalam Haritsah Kusumaningrum, 2008 Perkembangan bangunan Fungsi dan Peran Pasar Beringharjo, Yogyakarta, Skripsi Arkeologi, FIB UGM.

Gunarwan Suratmo, 2004, Analisis Mengenai Dampak Lingkungan. Jogjakarta, Gadjah Mada University Press.

Karden Eddy Sontang Manik, 2003, Pengelolaan Lingkungan Hidup, Penerbit Djambatan, Jakarta.

Kementrian Lingkungan Hidup Republik Indonesia, 2006, Peraturan Menteri Negara Lingkungan Hidup Noner 08 tahun 2006 tentang Pedoman Penyusunan Analisis Mengenai Dampak Lingkungan Hidup, Jakarta

Linus Suryadi AG, 1994, Nafas Budaya Yogyakarta, Yogyakarta: Bentang Offset.

Sektiadi, 2002, "Membayangkan Lodji Kecil", Jogja di Mataku, Kumpulan Artikel Alumni Arkeologi FIB UGM, belum diterbitkan.

Snyder, JC dan Catanese A.J., 1979, Introduction to Urban Planing, Mc, Graw Hill, New York.

Sonny Keraf, A., 2002, Etika Lingkungan, Jakarta: Penerbit Kompas,

Thomas F.King, 2002, Thinking Abaout Cultural Resource Management, Essays From the Edge.AltaMira Press, United Kingdom. 